\title{
PRESENCE OF HUMAN BOCAVIRUS 1 AND OTHER RESPIRATORY VIRUSES IN CHILDREN WITH LOWER RESPIRATORY TRACT INFECTION IN LATVIA
}

\author{
Anda Vilmane ${ }^{1, \#}$, Inga Ziemele ${ }^{2,3}$, Santa Rasa ${ }^{1}$, Anna Terentjeva ${ }^{1,5}$, Modra Murovska ${ }^{1}$, \\ Dace Gardovska ${ }^{2,3}$, Yung-Cheng Lin ${ }^{4}$, and Zaiga Nora-Krūkle ${ }^{1}$

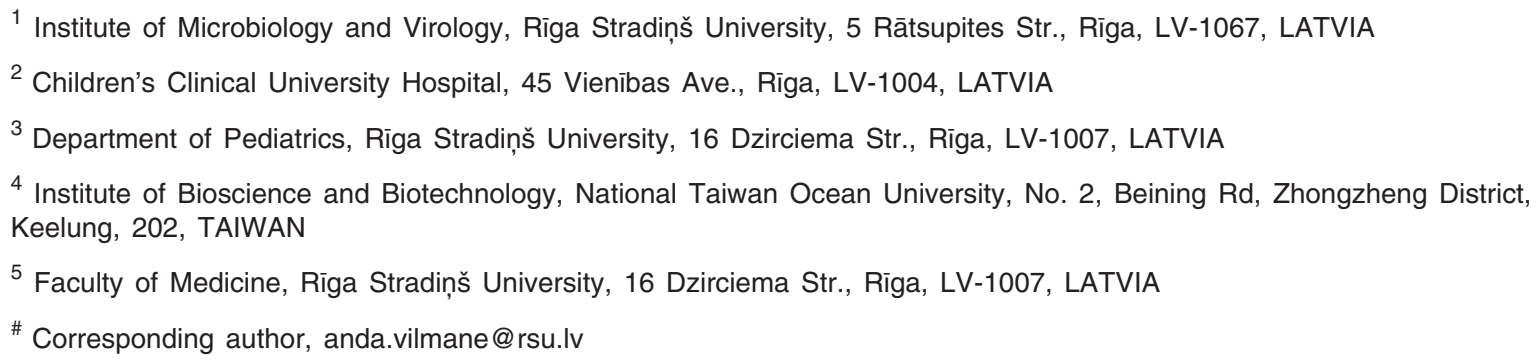

Contributed by Modra Murovska

Lower respiratory tract infection (LRTI) is the major cause of morbidity and mortality of children in the world. In addition to respiratory syncytial virus, influenza virus types $A$ and $B$, parainfluenza types 1, 2 and 3, and adenoviruses, several new respiratory viruses associated with LRTI were discovered in the $21^{\text {st }}$ century. These are metapneumovirus, coronaviruses NL63 and HKU1, parainfluenza virus type four and human bocavirus one (HBoV1). HBoV1 was discovered in 2005 and is considered as the fourth most prevalent respiratory virus worldwide. However, the high frequency of co-infections detected together with HBoV1 raises doubt about whether HBoV1 is a true pathogen or just a bystander. This is the first study aimed to determine the presence of HBoV1 and 18 other respiratory viruses in nasopharyngeal aspirates (NPA) of children with LRTI in Latvia. Using multiplex real-time polymerase chain reaction method, the HBoV1 genomic sequence was detected in $60.0 \%$ of NPA samples, showing that HBoV1 prevalence is high among children with LRTI in Latvia. HBoV1 mono-infection was revealed in $6.67 \%$. The most common co-infections associated with HBoV1 were rhinovirus, adenovirus, respiratory syncytial virus $A$ and $B$, metapneumovirus, and enterovirus.

Key words: parvovirus, infants, multiplex polymerase chain reaction.

\section{INTRODUCTION}

Viral upper and lower respiratory tract infection (LRTI) is one of the most common infections among humans and is the main cause of mortality of children up to five years of age (Berry et al., 2015). Viruses more commonly associated with aetiology of LRTI are respiratory syncytial virus, influenza virus types A and B, parainfluenza types 1, 2 and 3, and adenovirus types 1-5, 7, 14, 19 and 37 (Henrickson et al., 2004; Mahony, 2008; Nichols et al., 2008; Pavia, 2011). In the begining of the $21^{\text {st }}$ century, several new viruses associated with respiratory tract infections were discovered.
These are metapneumovirus, coronaviruses NL63 and HKU1, parainfluenza virus type 4 and human bocavirus 1 (HBoV1) (Pavia, 2011). In the case of respiratory tract diseases, simultaneous infection of more than one respiratory virus is often detected (Pinky and Dobrovolny, 2016). Unfortunately, it is not possible to determine the exact aetiological agent based on clinical signs only (Pavia, 2011).

HBoV1, which belongs to the Parvoviridae family, Parvovirinae subfamily, Bocaparvovirus genus, was discovered in 2005 in airway specimens of patients with respiratory diseases (Allander et al., 2005). Since then it has been 
found worldwide throughout the year in about 2 to $20 \%$ of airway samples of symptomatic as well as asymptomatic individuals, mainly aged from six months to five years, with upper respiratory tract infection or LRTI (Jartti et al., 2012; Qiu et al., 2016.). HBoV1 is considered as the fourth most prevalent respiratory virus in the world (Tabasi et al., 2016). Currently three more HBoVs are known - HBoV2, $\mathrm{HBoV} 3$, and HBoV4. These viruses were discovered in stool samples of patients with gastroenteritis (Kapoor et al., 2009; Arthur et al., 2009; Kapoor et al., 2010) and are not considered as respiratory pathogens.

Respiratory tract diseases are a serious problem also in the children population of Latvia. According to data from the Disease Prevention and Control Centre of Latvia, respiratory tract diseases are the major reason of morbidity for children under one year of age.

This is the first study in Latvia reflecting the presence of HBoV1 and 18 other respiratory viruses in airway samples of pediatric patients with LRTI.

The aim of this study was to determine the presence of HBoV1 and its co-infection with 18 other respiratory viruses in nasopharyngeal aspirates (NPA) of children with LRTI in Latvia.

\section{MATERIALS AND METHODS}

Patients and sample collection. The study was conducted in accordance with safety standards, the study protocol was approved by the Ethics Committee of Rīga Stradiňš University on 30 May 2013 (permission code: 25/30.05.2013). Written informed consent was received from all parents/ guardians of participating children.

Inclusion criteria were as follows: pediatric patients aged from one to 60 months treated as inpatients for LRTI at the Department of Pediatrics, Children's Clinical University Hospital in Rìga, Latvia. In accordance with Roth et al. (2008), diagnosis of LRTI was defined as having at least one of the following clinical signs: fast or difficult breathing, chest wall indrawing, and abnormal auscultatory findings (crackles/crepitations or bronchial breath sounds). Fast breathing was defined in accordance with World Health Organization (WHO) criteria (Anonymous, 1995). All patients had a fever $\left(>37.5^{\circ} \mathrm{C}\right)$ at the time of NPA sampling. Patient' clinical status was evaluated by a physician and only patients presenting with symptoms typical for viral infection were included in the study cohort. Children presenting with symptoms more than ten days of acute illness as well as those with severe chronic underlying illnesses were excluded.

In total, 90 children ( $60 \%$ male and $40 \%$ female), median age 23 months (range from two to 59 months) with LRTI during the period from October 2013 to December 2016 were included in this study. NPA were collected on admission and transported to the Institute of Microbiology and
Virology, Rīga Stradiņš University, for virological examination.

In order to assess the prevalence rate of viral co-infections among different age groups, patients were divided into three groups. $1^{\text {st }}$ group: $0-11$ months $(\mathrm{n}=14 ; 7$ male, 7 female), $2^{\text {nd }}$ group: $12-23$ months ( $\mathrm{n}=33 ; 17$ male, 16 female $)$ and $3^{\text {rd }}$ group: $24-60$ months $(\mathrm{n}=43$; male 30 , female 13$)$.

Laboratory methods. Total DNA was extracted from NPAs using standard phenol-chloroform extraction method. Quantity of extracted DNA was tested spectrophotometrically and quality checked by determining the presence of a $\beta$-globin gene sequence by polymerase chain reaction (PCR).

We tested for the presence of 19 respiratory viruses in DNA samples using commercially available multiplex real-time PCR kits (Allplex Respiratory Panel 1; Allplex Respiratory Panel 2; Allplex Respiratory Panel 3) manufactured by Seegene (Seoul, South Korea). PCR was performed using CFX96 Deep Well Real-Time Detection System (Bio-Rad, California, USA). Obtained results were analysed by BioRad CFX Manager IVD and Seegene Viewer for Real time Instruments v2.0 software.

The examined viruses were: influenza A virus (Flu A) with subtypes H1; H3 and H1pdm09; influenza B virus (Flu B); respiratory syncytial virus (RSV) A and RSV B; adenovirus (AdV) almost all of B, C and E types and some of A, D and F types; metapneumovirus (MPV); enterovirus (HEV) almost all of A, B and some of $\mathrm{C}$ and $\mathrm{D}$ types; parainfluenza virus (PIV) 1/2/3/4; human bocavirus 1/2/3/4 (HBoV); rhinovirus A/B/C (HRV); coronavirus 22(C) 9E, NL63 and OC43.

To confirm the presence of $\mathrm{HBoV} 1$ in $\mathrm{HBoV}$ positive DNA samples, PCR using primers specific to the HBoV1 NS1 gene sequence was performed in accordance with Sloots et al., 2006. PCR products were analysed electrophoretically in $1.7 \%$ agarose gel with the expected PCR product size of $300 \mathrm{bp}$.

Data analysis. Sowtware GraphPad Prism 7 and Software Excel 2016 were used for statistical analysis and data visualisation. The Fisher's exact test and unpaired t test were performed to estimate the differences and Spearman's correlation to test for significant relationships. A $p$ value < 0.05 was considered statistically significant.

\section{RESULTS}

Distribution of respiratory viruses among different age groups. Presence of respiratory viruses as mono-infections (defined as identification of a single viral pathogen in one sample) as well as co-infections (defined as identification of more than one viral pathogen in the same sample) in NPA samples of children with LRTI is summarised in Table 1. Co-infection of more than one respiratory virus was detected more often than mono-infection. As it is seen in Fig- 
Table 1

PRESENCE OF RESPIRATORY VIRUSES (AS MONO- AND CO-INFECTIONS) AMONG DIFFERENT AGE GROUPS IN CHILDREN WITH LRTI

\begin{tabular}{|c|c|c|c|c|}
\hline & $\begin{array}{c}1^{\text {st }} \text { group } \\
(0-11 \\
\text { months } \\
\mathrm{n}=14)\end{array}$ & $\begin{array}{c}2^{\text {nd }} \text { group } \\
(12-23 \\
\text { months, } \\
n=33)\end{array}$ & $\begin{array}{c}3^{\text {rd }} \text { group } \\
(24-60 \\
\text { months, } \\
\mathrm{n}=43)\end{array}$ & $\begin{array}{c}\text { Total } \\
(0-60 \\
\text { months, } \\
\mathrm{n}=90)\end{array}$ \\
\hline & $\begin{array}{c}\mathrm{N}(\text { single }+ \\
\text { co-infection })\end{array}$ & $\begin{array}{c}\mathrm{N}(\text { single }+ \\
\text { co-infection })\end{array}$ & $\begin{array}{c}\mathrm{N}(\text { single }+ \\
\text { co-infection) }\end{array}$ & $\begin{array}{c}\mathrm{N} \text { (single }+ \\
\text { co-infection) }\end{array}$ \\
\hline $\mathrm{HBoV}$ & $6(1+5)$ & $20(2+18)$ & $28(3+25)$ & $54(6+48)$ \\
\hline HRV & $5(2+3)$ & $13(3+10)$ & $14(5+9)$ & $32(10+22)$ \\
\hline $\mathrm{AdV}$ & $3(0+3)$ & $7(0+7)$ & $15(0+15)$ & $25(0+25)$ \\
\hline RSV A & $5(0+5)$ & $9(1+8)$ & $10(3+7)$ & $24(4+20)$ \\
\hline RSV B & $3(1+2)$ & $4(2+2)$ & $9(1+8)$ & $16(4+12)$ \\
\hline $\mathrm{HEV}$ & $1(0+1)$ & $2(0+2)$ & $5(1+4)$ & $8(1+7)$ \\
\hline MPV & $1(0+1)$ & $4(1+3)$ & $3(0+3)$ & $8(1+7)$ \\
\hline PIV 1 & $0(0+0)$ & $0(0+0)$ & $1(0+1)$ & $1(0+1)$ \\
\hline PIV 2 & $0(0+0)$ & $0(0+0)$ & $2(0+2)$ & $2(0+2)$ \\
\hline PIV 3 & $0(0+0)$ & $3(0+3)$ & $2(0+2)$ & $5(0+5)$ \\
\hline FluA H1 & $1(0+1)$ & $0(0+0)$ & $0(0+0)$ & $1(0+1)$ \\
\hline FluAH1pdm09 & $0(0+0)$ & $0(0+0)$ & $1(0+1)$ & $1(0+1)$ \\
\hline FluA H3 & $1(0+1)$ & $0(0+0)$ & $0(0+0)$ & $1(0+1)$ \\
\hline Flu B & $1(0+1)$ & $1(0+1)$ & $0(0+0)$ & $2(0+2)$ \\
\hline C229E & $1(0+1)$ & $1(0+1)$ & $1(0+1)$ & $3(0+3)$ \\
\hline COC43 & $0(0+0)$ & $3(0+3)$ & $1(0+1)$ & $4(0+4)$ \\
\hline CNL63 & $0(0+0)$ & $1(1+0)$ & $0(0+0)$ & $1(1+0)$ \\
\hline PIV 4 & $0(0+0)$ & $0(0+0)$ & $0(0+0)$ & $0(0+0)$ \\
\hline
\end{tabular}

LRTI, lower respiratory tract infection; N, number of patients with corresponding virus infection

ure 1 , there were cases in each age group where none of the respiratory viruses were detected (in the $1^{\text {st }}(0-11$ months) and $2^{\text {nd }}$ (12-23 months) group - one case in each group and in the $3^{\text {rd }}$ (24-60 months) group - two cases). The number of viruses detected simultaneously among age groups (ranging from 1 to 6 viruses) is shown in Figure 1.

For all age groups, DNA samples that were $\mathrm{HBoV}$ positive by multiplex PCR were also positive for HBoV1 specific PCR, showing that HBoV1 is present in respiratory specimens of children with LRTI in Latvia.

In total, the HBoV1 genomic sequence was detected in $60.0 \%$ of DNA samples extracted from NPA. In all three age groups HBoV1 was the most frequently detected virus. HBoV1 positivity (proportional as \%) significantly differed between the $1^{\text {st }}$ and $2^{\text {nd }}$ age groups $(p=0.0159)$ and between the $1^{\text {st }}$ and $3^{\text {rd }}$ age groups $(p=0.0028)$ (Fig. 2).

HBoV1 and co-infections. In the $1^{\text {st }}$ age group the most common co-infections detected together with HBoV1 were HRV and RSV A (two cases of each virus) followed by HEV, MPV, AdV, RSV B, FluA H1, FluA H3, and FluB (one case of each virus). In the $2^{\text {nd }}$ age group the most frequently detected co-infections with HBoV1 were HRV

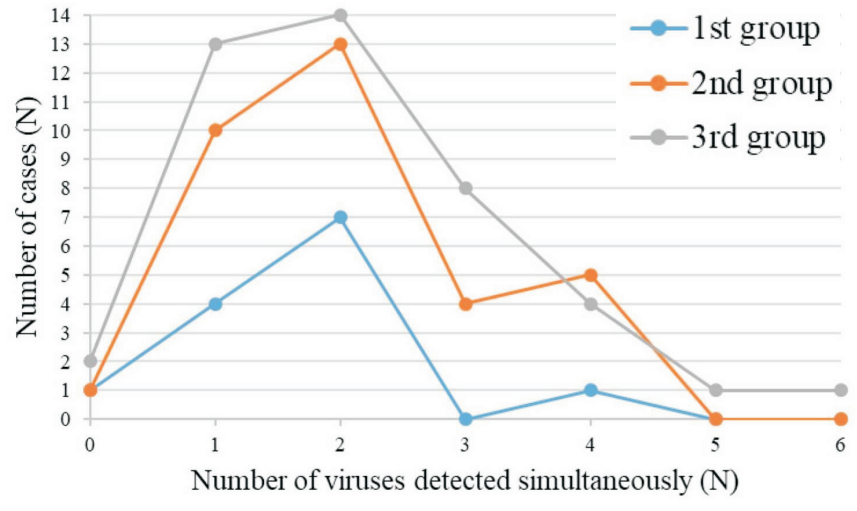

Fig. 1. Number of respiratory viruses detected among age groups of children with lower respiratory tract infection.

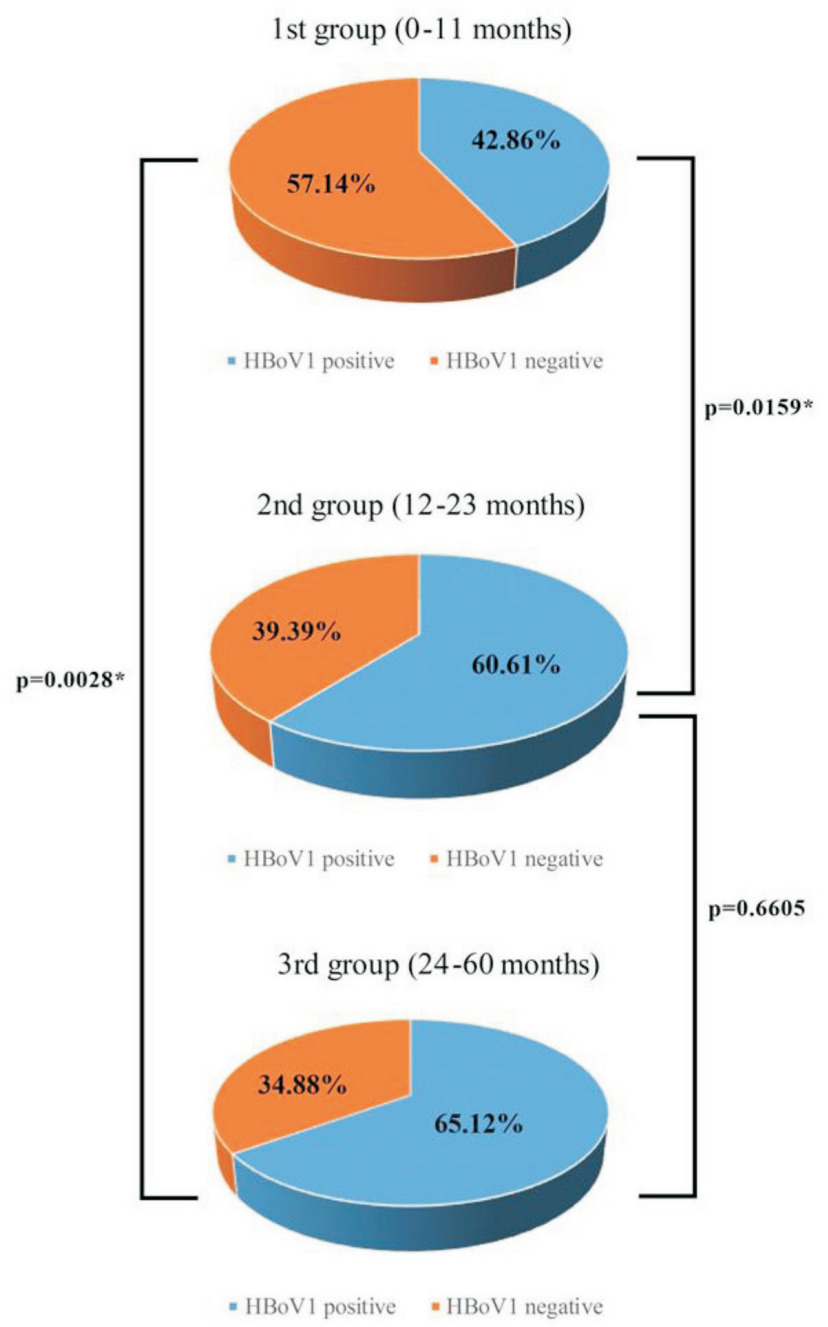

Fig. 2. HBoV1 positivity (\%) among age groups of children with lower respiratory tract infection; $p$ values are Fisher's exact test results between age groups showing differences among HBoV1 positivity; * statistically significant.

(eight cases), followed by RSV A (six cases), AdV (four cases), PIV 3, and coronavirus OC43 (two cases each), $\mathrm{HEV}$ and FluB (one case). In the $3^{\text {rd }}$ group the frequency of co-infections with HBoV1 was as follows: AdV (12 cases), HRV and RSV B (eight cases each), RSV A (six cases), HEV (three cases), MPV and PIV 2 (each - two cases), 

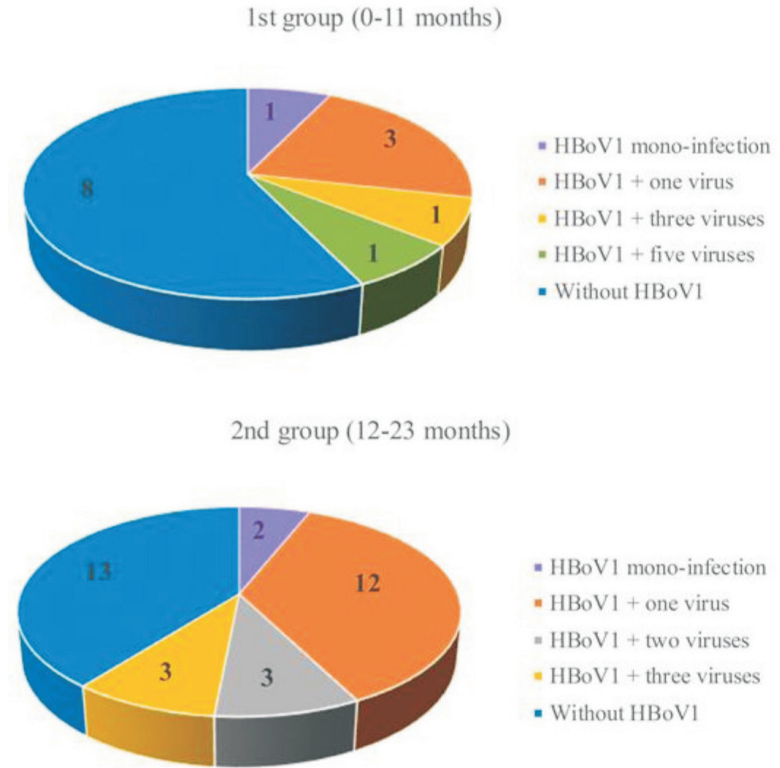

3rd group (24-60 months)

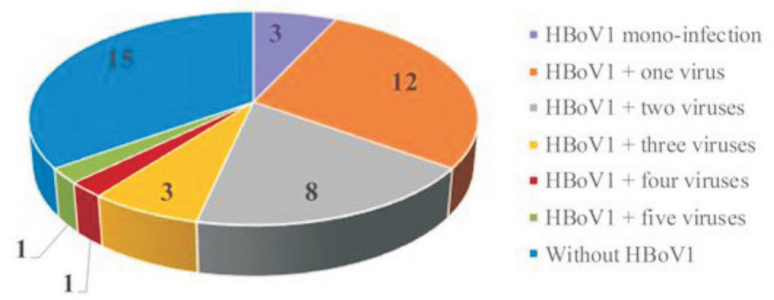

Fig. 3. HBoV1 mono-infection and number of viruses detected simultaneously with $\mathrm{HBoV} 1$ in children with lower respiratory tract infection; Numbers are representing the number of cases.

PIV 1, PIV 3, coronaviruses 229E, OC43 and pdm09 (one case each). There was no statistically significant correlation between $\mathrm{HBoV}$ and any of the co-infections among age groups (data not shown). Numbers of viruses detected in co-infection with HBoV1 are represented in Figure 3. HBoV1 infection simultaneously with one respiratory virus was the most frequent combination in the study group.
Mono-infection. HBoV1 mono-infection was revealed in six cases (one case in the $1^{\text {st }}$ group, two cases in the $2^{\text {nd }}$ group and three cases in the $3^{\text {rd }}$ group), HRV - in 10 cases (two cases in the $1^{\text {st }}$ group, three cases in the $2^{\text {nd }}$ group and five cases in the $3^{\text {rd }}$ group), RSV A - in four cases (one case in the $2^{\text {nd }}$ group and three in the $3^{\text {rd }}$ group), RSV B four cases $\left(1^{\text {st }}\right.$ group - one case, $2^{\text {nd }}$ group - two cases and $3^{\text {rd }}$ group - one case), HEV in one case ( $3^{\text {rd }}$ group) and NL63 in one case ( $2^{\text {nd }}$ group).

Patients' clinical characteristics. According to the International Statistical Classification of Diseases and Related Health Problems, $10^{\text {th }}$ Revision, J20 (acute bronchitis), J21 (acute bronchiolitis), and J18.0 (unspecified bronchopneumonia) were the main diagnoses for the study cohort. Clinical diagnoses and average duration of hospitalisation by age group are summarised in Table 2. For some individuals in each age group, in addition to clinical diagnosis, unspecified bronchopneumonia was diagnosed as a complication of the disease - in the $1^{\text {st }}$ age group in three cases (one case with primary diagnosis of acute bronchiolitis, two cases with acute bronchitis), in the $2^{\text {nd }}$ group in nine cases, of which acute bronchitis as a primary diagnosis occurred in eight cases, and acute bronchiolitis in one case. In the $3^{\text {rd }}$ group, bronchopneumonia as a complication was present in seven cases with acute bronchitis as a main diagnosis in all cases. No significant difference occurred in any of the age groups between $\mathrm{HBoV} 1$ positive and $\mathrm{HBoV} 1$ negative patients in duration of hospitalisation (in days) were compared ( $p=0.6861 ; p=0.3385 ; p=0.2925$, respectively, for the age groups).

\section{DISCUSSION}

Viruses play an important role in the aetiology of respiratory diseases, but in most of the cases the causative agent remains unknown, mainly because clinical signs and symptoms usually are not virus specific. Common co-infection with more than one respiratory virus even more complicates the situation. Therefore, usage of molecular methods such as multiplex PCR is a convenient approach to improve the diagnostics of respiratory infections on a daily basis. Sev-

CLINICAL DIAGNOSIS AND AVERAGE DURATION OF HOSPITALISATION OF CHILDREN WITH LRTI

\begin{tabular}{|c|c|c|c|c|c|}
\hline \multicolumn{4}{|c|}{ Diagnosis } & \multirow{2}{*}{$\begin{array}{l}\text { Average duration of } \\
\text { hospitalisation } \\
\text { of HBoV1 positive } \\
\text { patients (days) }\end{array}$} & \multirow{2}{*}{$\begin{array}{l}\text { Average duration of } \\
\text { hospitalisation } \\
\text { of HBoV1 } \\
\text { negative patients } \\
\text { (days) }\end{array}$} \\
\hline & $\begin{array}{c}\text { Unspecified } \\
\text { bronchopneumonia } \\
\mathrm{N} \\
\text { (HBoV1 positive) }\end{array}$ & $\begin{array}{c}\text { Acute } \\
\text { bronchitis } \\
\mathrm{N} \\
\text { (HBoV1 positive) }\end{array}$ & $\begin{array}{c}\text { Acute } \\
\text { bronchiolitis } \\
\mathrm{N} \\
\text { (HBoV1 positive) }\end{array}$ & & \\
\hline $\begin{array}{l}1^{\text {st }} \text { group } \\
(0-11 \text { months })\end{array}$ & $5(1)$ & $10(4)$ & $2(1)$ & 5 & 4.5 \\
\hline $\begin{array}{l}2^{\text {nd }} \text { group } \\
\text { (12-23 months) }\end{array}$ & $20(10)$ & $21(13)$ & $2(1)$ & 5.5 & 4.3 \\
\hline $\begin{array}{l}3^{\text {rd }} \text { group } \\
(24-60 \text { months })\end{array}$ & $29(19)$ & $23(13)$ & $0(0)$ & 4.1 & 3.3 \\
\hline
\end{tabular}

LRTI, lower respiratory tract infection; N, number of patients 
eral publications have already described high sensitivity and specifity of multiplex PCR in detection of single or multiple respiratory viruses and can also be used to distinguish between acute viral and bacterial infection, thereby increasing the chance of reducing the use of unnecessarry antibiotics in treatment (Krause et al., 2014; Ljubin-Sternak et al., 2016; Bhuiyan et al., 2018).

In the last years, molecular diagnostics have become more accessible in hospitals worldwide and in Latvia. Since 2012, HBoV1 testing is conducted routinely in the Children's Clinical University Hospital in Rīga. However, since HBoV1 can be detected in the respiratory tract even several months after infection, interpretation of causal agent becomes difficult in cases of co-infection. In the case of HBoV1 mono-infection accompanied by clinical symptoms characteristic of virus infection, it is clear that this virus is the responsible pathogen. However practitioners in Latvia are not well informed regarding the pathogenic properties of HBoV1 and often the result of the presence of this virus is not perceived with the severity it deserves. This is the first study in Latvia showing the presence of HBoV1 as monoinfection as well as co-infection with other respiratory viruses, has given new insights in the role of HBoV1 in causing diseases.

In this study HBoV1 was the most commonly detected respiratory virus in all age groups, reaching $65.12 \%$ positivity in the group aged from 24 to 60 months, $60.61 \%$ in the group from 12 to 23 months and $42.86 \%$ positivity in group aged from 0 to 11 months. HBoV1 was detected significantly more often in patients from the $2^{\text {nd }}$ and $3^{\text {rd }}$ groups, in comparison with patients from the $1^{\text {st }}$ group ( $p=0.0159$ and $p=0.0028$ ). This finding coincides with results from other studies, where HBoV1 was more frequent in patients aged from six months up to five years of age (Arnold et al., 2006; Kesebir et al., 2006; Manning et al., 2006; Fry et al., 2007). Most likely, HBoV1 seropositivity derived from mothers via vertical antibody transfer protects infants from infection with HBoV1 during the first few months of life (Endo et al., 2007; Kahn et al., 2008). In the present study only one case of HBoV1 was detected in NPA of child younger than six months. It has been shown that the lowest HBoV1 IgG antibody detection rate occurs in children from six to 24 months of age. After this period, HBoV1 seropositivity increases and at the age of five years $\sim 90 \%$ of children have circulating antibodies against HBoV1 (Endo et al., 2007; Wang et al., 2010; Kantola et al., 2015).

In the present study $\mathrm{HBoV} 1$ positivity was at least three times higher $(60 \%)$ than the average HBoV1 prevalence globally, which ranges from 2 to 20\% (Qiu et al., 2017). The relatively high $\mathrm{HBoV} 1$ positivity in our study can be explained by selecting patients not older than 60 months and presenting symptoms typical for viral infection. Also in most of the studies, HBoV1 was detected using nested or real-time PCR methods that are often less sensitive than the multiplex real-time PCR used in the present study. On the other hand, some studies have reported a high HBoV1 de- tection rate. In a study conducted in the United States of America, $\mathrm{HBoV} 1$ positivity reached $59 \%$ in respiratory samples from symptomatic as well as asymptomatic children (Martin et al., 2010), while in a study carried out in Canada, HBoV1 positivity among asymptomatic children was $43 \%$ (Longtin et al., 2008) showing relatively high HBoV1prevalence among the children population not only in Latvia.

Several studies showed that HBoV1 mono-infection is rare and that the co-infection rate among $\mathrm{HBoV} 1$ positive cases is up to $90 \%$, which raises a question of whether HBoV1 is a true pathogen or a bystander (Fry et al., 2007; Christensen et al., 2008; Miron et al., 2010). To better understand whether HBoV1 is a causative agent of the disease, it would be necessary to determine the presence of HBoV1-specific IgM class antibodies, thus indicatin acute infection. In this study HBoV1 mono-infection is revealed in $6.67 \%$ of all HBoV1 positive cases. In the present study, the most commonly detected co-infections with HBoV1 were HRV (37.50\%), AdV (35.42\%), RSV A (29.17\%), RSV B (20.83\%), MPV (10.42\%) and HEV (10.42\%). Our findings of co-infections are in line with results obtained by other research groups. For example, a group from China reported that RSV and HRV were the most frequently detected co-infections with HBoV1 (Sun et al., 2018). Also in other studies, RSV, HRV, AdV, MPV, and HEV are mentioned as the most common co-infections with HBoV1 (Wang et al., 2010; Calvo et al., 2016; Liu et al., 2018).

In the present study HBoV1 infection was not related to the duration of hospitalisation and did not cause specific clinical symptoms, but one patient from the study cohort with HBoV1 mono-infection had severe LRTI. This case was described in a case report (submitted for publication in the Journal of Medical Case Reports). There have been reports of more severe clinical manifestations in $\mathrm{HBoV} 1$ positive patients in comparison with those without HBoV1 infection. In a research carried out in Japan, hypoxia and neutrophilia were more severe in HBoV1-positive than in RSV-positive children with LRTI (Moriyama et al., 2010). Several case reports described $\mathrm{HBoV1}$-induced clinical features, including respiratory tract diseases as well as myocarditis, lung and colorectal tumours (Jula et al., 2013; Schildgen et al., 2013; Brebion et al., 2014) suggesting HBoV1 as a true pathogen in a wide range of diseases. Furthermore, in several studies HBoV1 has been detected in cerebrospinal fluid samples of patients with encephalitis, showing its ability to cross the blood-brain barrier and enter the central nervous system (Mitui et al., 2012; Mori et al., 2013; Yu et al., 2013).

The results of the present study indicate that HBoV1 prevalence among children with LRTI is relatively high in Latvia and that $\mathrm{HBoV} 1$ infection is most frequently present in children aged from 12 to 60 months. Although HBoV1 mono-infection in case of LRTI is rare it should be treated as a serious pathogen when accompanied with clinical signs 
and symptoms. The most common co-infections with HBoV1 are HRV, AdV, RSV A, RSV B, MPV, and HEV.

\section{ACKNOWLEDGEMENTS}

This study was supported by project No. RSU ZP 17/2013 "Epidemiology, pathogenicity of human bocavirus ( $\mathrm{HBoV})$ species and possible association with lower respiratory tract illneses and acute gastroenteritis in children" and cooperation project of the Taiwan-Latvia-Lithuania Mutual Funds "Establishing of the framework to track molecular epidemiology of Parvoviruses and to correlate sequence variability with different clinical manifestations".

\section{REFERENCES}

Allander, T., Tammi, M. T., Eriksson, M., Bjerkner, A., Tiveljung-Lindell, A., Anderson, B. (2005). Cloning of a human parvovirus by molecular screening of respiratory tract samples. Proc. Natl. Acad. Sci. USA, 102 (36), 12891-12896

Anonymous (1995). The Management of Acute Respiratory Infections in Children: Practical Guidelines for Outpatient Care. World Health Organization, Geneva. 75 pp.

Arthur, J. L., Higgins, G. D., Davidson, G. P., Givney, R. C., Ratcliff, R. M. (2009). A novel bocavirus associated with acute gastroenteritis in Australian children. PLoS Pathogens, 5 (4), e1000391.

Berry, M., Gamieldien, J., Fielding, B. C. (2015). Identification of new respiratory viruses in the new millennium. Viruses, 7 (3), 996-1019.

Bhuiyan, M. U., Snelling, T. L., West, R., Lang, J., Rahman, T., Borland, M. L., Thornton, R., Thornton, L. A., Sikazwe, C., Martin, A. C., Richmond, P. C., Smith, D. W., Jaffe, A., Blyth, C. C. (2018). Role of viral and bacterial pathogens in causing pneumonia among Western Australian children: A case-control study protocol. BMJ Open, v.8(3), e020646.

Brebion, A., Vanlieferinghen, P., Déchelotte, P., Boutry, M., PeigueLafeuille, H., Henquell, C. (2014). Fatal subacute myocarditis associated with human bocavirus 2 in a 13-month-old child. J. Clin. Microbiol., 52 (3), 1006-1008.

Calvo, C., García-García, M. L., Pozo, F., Carballo, D., MartínezMonteserín, E., Casas, I. (2016). Infections and coinfections by respiratory human bocavirus during eight seasons in hospitalized children. $J$. Med. Virol., 88 (12), 2052-2058.

Christensen, A., Nordbø, S. A., Krokstad, S., Rognlien, A. G., Døllner, H. (2008). Human bocavirus commonly involved in multiple viral airway infections. J. Clin. Virol., 41 (1), 34-37.

Endo, R., Ishiguro, N., Kikuta, H., Teramoto, S., Shirkoohi, R., Ma, X., Ebihara, T., Ishiko, H., Ariga, T. (2007). Seroepidemiology of human bocavirus in Hokkaido prefecture, Japan. J. Clin. Microbiol., 45 (10), 3218-3223.

Fry, A. M., Lu, X., Chittaganpitch, M., Peret, T., Fischer, J., Dowell, S. F., Anderson, L. J., Erdman, D., Olsen, S. J. (2007). Human bocavirus: A novel parvovirus epidemiologically associated with pneumonia requiring hospitalization in Thailand. J. Infect. Dis., 195 (7), 1038-1045.

Henrickson, K. J., Hoover, S., Kehl, K. S., Hua, W. (2004). National disease burden of respiratory viruses detected in children by polymerase chain reaction. Ped. Infect. Dis. J., 23 (1 Suppl), S11-S8.

Jula, A., Waris, M., Kantola, K., Peltola, V., Söderlund-Venermo, M., Hedman, K., Ruuskanen, O. (2013). Primary and secondary human bocavirus 1 infections in a family, Finland. Emerg. Infect. Dis. J., 19 (8), 1328-1331.

Kahn, J. S., Kesebir, D., Cotmore, S. F., D'Abramo, A., Cosby, C., Weibel, C., Tattersall, P. (2008). Seroepidemiology of human bocavirus defined using recombinant virus-like particles. J. Infect. Dis., 198 (1), 41-50.
Kantola, K., Hedman, L., Allander, T., Jartti, T., Lehtinen, P., Ruuskanen, O., Hedman, K., Söderlund-Venermo, M. (2008). Serodiagnosis of human bocavirus infection. Clin. Infect. Dis., 46 (4), 540-546.

Kapoor, A., Slikas, E., Simmonds, P., Chieochansin, T., Naeem, A., Shaukat, S., Alam, M. M., Sharif, S., Angez, M., Zaidi, S., Delwart, E. (2009). A new bocavirus species in human stool. J. Infect. Dis., 199 (2), 196-200.

Kapoor, A., Simmonds, P., Slikas, E., Li L., Bodhidatta, L., Sethabutr, O., Triki, H., Bahri, O., Oderinde, B. S., Baba, M. M., Bukbuk, D. N., Besser, J., Bartkus, J., Delwart, E. (2010). Human bocaviruses are highly diverse, dispersed, recombination prone, and prevalent in enteric infections. J. Infect. Dis., 201 (11), 1633-1643

Krause, J. C., Panning, M., Hengel, H., Henneke, P. (2014). The role of multiplex PCR in respiratory tract infections in children. Deutsches Arzteblatt International, v.111(38), 639-645.

Liu, W. K., Liu, Q., Chen, D. H., Tan, W. P., Cai, Y., Qiu, S. Y., Xu, D., Li, C., Li, X., Lin, Z. S., Zhou, R. (2018). Epidemiology of HBoV1 infection and relationship with meteorological conditions in hospitalized pediatric patients with acute respiratory illness: A 7-year study in a subtropical region. BMC Infect. Dis., v.18.

Ljubin-Sternak, S., Marijan, T., Ivković-Jureković, I., Čepin-Bogović, J., Gagro, A., Vraneš, J. (2016). Etiology and clinical characteristics of single and multiple respiratory virus infections diagnosed in Croatian children in two respiratory seasons. J. Pathog., 2016, 2168780.

Longtin, J., Bastien, M., Gilca, R., Leblanc, E., de Serres, G., Bergeron, M. G., Boivin, G. (2008). Human bocavirus infections in hospitalized children and adults. Emerg. Infect. Dis. J., 14 (2), 217-221.

Mahony, J. B. (2008). Detection of respiratory viruses by molecular methods. Clin. Microbiol. Rev., 21 (4), 716-747.

Martin, E. T., Fairchok, M. P., Kuypers, J., Magaret, A., Zerr, D. M., Wald, A., Englund, J. A. (2010). Frequent and prolonged shedding of bocavirus in young children attending daycare. J. Infect. Dis., 201 (11), 1625-1632.

Miron, D., Srugo, I., Kra-Oz, Z., Keness, Y., Wolf, D., Amirav, I., Kassis, I. (2010). Sole pathogen in acute bronchiolitis: is there a role for other organisms apart from respiratory syncytial virus? Ped. Infect. Dis. J., 29 (1), e7-e10.

Mitui, M. T., Tabib, S. M. S. B., Matsumoto, T., Khanam, W., Ahmed, S., Mori, D., Akhter, N., Yamada, K., Kabir, L., Nishizono, A., SöderlundVenermo, M., Ahmed, K. (2012). Detection of human bocavirus in the cerebrospinal fluid of children with encephalitis. Clin. Infect. Dis., 54, 964-967.

Mori, D., Ranawaka, U., Yamada, K., Rajindrajith, S., Miya, K., Perera, K. H. K., Matsumoto, T., Dassanayake, M., Mitui, M. T., Mori, H., Nishizono, A., Söderlund-Venermo, M., Ahmed, K. (2013). Human bocavirus in patients with encephalitis, Sri Lanka, 2009-2010. Emerg. Infect. Dis. J., 19 (11), 1859-1862

Moriyama, Y., Hamada, H., Okada, M., Tsuchiya, N., Maru, H., Shirato, Y., Maeda, Y., Hirose, Y., Yoshida, M., Omura, Y., Honda, T., Muto, A., Hayashi, K., Terai, M. (2010). Distinctive clinical features of human bocavirus in children younger than 2 years. Eur. J. Ped., 169 (9), 1087-1092.

Nichols, W. G., Campbell, A. J. P., Boeckh, M. (2008). Respiratory viruses other than influenza virus: Impact and therapeutic advances. Clin. Microbiol. Rev., 21 (2), 274-290.

Jartti, T., Hedman, K., Jartti, L., Ruuskanen, O., Allander, T., Söderlund-Venermo, M. (2012). Human bocavirus - the first 5 years. Rev. Med. Virol., 22, 46-64.

Pavia, A. T. (2011). Viral infections of the lower respiratory tract: Old viruses, new virusies, and role of diagnosis. Clin. Infect. Dis., 52 S284-S289.

Pinky, L., Dobrovolny, H. M. (2016). Coinfections of the respiratory tract: Viral competition for resources. PloS One, 11 (5), e0155589.

Qiu, J., Söderlund-Venermo, M., Young, N. S. (2017). Human parvoviruses. Clin. Microbiol. Rev., 30 (1), 43-113. 
Roth, D. E., Caulfield, L. E., Ezzati, M., Black, R. E. (2008). Acute lower respiratory infections in childhood: Opportunities for reducing the global burden through nutritional interventions. Bull. World Health Org., 86, Suppl 5, 356-364.

Schildgen, V., Malecki, M., Tillmann, R. L., Brockmann, M., Schildgen, O. (2013). The human bocavirus is associated with some lung and colorectal cancers and persists in solid tumors. PLoS One, 8 (6), e68020.

Sun, H., Sun, J., Ji, W., Hao, C., Yan, Y., Chen, Z., Wang, Y. (2018). Impact of RSV coinfection on human bocavirus in children with acute respiratory infections. J. Trop. Ped., doi: 10.1093/tropej/fmy057.

Received 5 November 2018

Accepted in the final form 11 February 2019
Tabasi, M., Mokhtari-Azad, T., Eshraghian, M. R., Shadab, A., Shatizadeh, S., Nazanin Shafiei-Jandaghi, Z., Yavarian, J. (2016). Human bocavirus infections among children less than two years old in Iran during fall and winter 2012-2013. Iran. J. Microbiol., 8 (1), 80-84.

Wang, K., Wang, W., Yan, H., Ren, P., Zhang, J., Shen, J., Deubel, V. (2010). Correlation between bocavirus infection and humoral response, and co-infection with other respiratory viruses in children with acute respiratory infection. J. Clin. Virol., 47 (2), 148-155.

Yu, J. M., Chen, Q. Q., Hao, Y. X., Yu, T., Zeng, S. Z., Wu, X. B., Zhang, B., Duan, Z. J. (2013). Identification of human bocaviruses in the cerebrospinal fluid of children hospitalized with encephalitis in China. $J$. Clin. Virol., 57 (4), 374-377. 16.

\section{CILVĒKA BOKAVĪRUSA 1 UN CITU RESPIRATORO VĪRUSU KLĀTBŪTNE BĒRNIEM AR DZIL,O ELPCEL̨U INFEKCIJU LATVIJĀ}

Dziḷo elpceḷu infekcija ir galvenais cēlonis bērnu saslimšanai un mirstībai visā pasaulē. Vìrusi, kurus visbiežāk saista ar dziḷo elpceḷu infekciju, ir respiratori sincitiālais vīruss, A un B tipa gripas vīruss, kā arī pirmā, otrā un trešā tipa paragripas vīruss un adenovīrusi. 21. gadsimtā atklāti vairāki jauni respiratorie vīrusi, ko saista ar dziḷo elpceḷu infekciju izraisišsanu. Tie ir metapneimovīruss, koronavīrusi NL63 un HKU1, paragripas ceturtā tipa vīruss un cilvēka bokavīruss 1 (HBoV1). HBoV1 atklāts 2005. gadā un tiek uzskatīts par ceturto izplatītāko respiratoro vīrusu pasaulē. Šì pētījuma mērkis bija noteikt HBoV1 un 18 citu respiratoro vīrusu klātbūtni nazofaringeālo aspirātu paraugos no bērniem ar dziḷo elpceḷu infekciju Latvijā. Izmantojot multipleksētu reālā laika polimerāres k,ēdes reakcijas metodi, HBoV1 genoma sekvence tika noteikta 60,0\% nazofaringeālo aspirātu paraugos; tas liecina, ka HBoV1 prevalence, bērnu ar dziḷo elpceḷu slimībām, vidū Latvijā ir augsta. HBoV1 mono-infekciju konstatēja 6,67\% gadījumu. Visbiežāk detektêtās koinfekcijas ar HBoV1 bija rinovīruss, adenovīruss, respiratori sincitiālais vīruss $\mathrm{A}$ un $\mathrm{B}$, metapneimovīruss un enterovīruss. 